\title{
Phenotypic and phylogenetic characterization of a novel Lactobacillus species from human sources: description of Lactobacillus iners sp. nov.
}

\author{
Enevold Falsen, ${ }^{1}$ Christina Pascual, ${ }^{2}$ Berit Sjödén, ${ }^{1}$ Maria Ohlén ${ }^{1}$ \\ and Matthew D. Collins ${ }^{2} \dagger$
}

Author for correspondence: Matthew D. Collins. Tel: +44 1189 357000. Fax: +44 1189267917. e-mail: david.collins@bbsrc.ac.uk

1 Culture Collection, Department of Clinical Bacteriology, University of Goteborg, Göteborg, Sweden

2 BBSRC Institute of Food Research, Reading Laboratory, Reading RG6 6BZ, UK

\begin{abstract}
Eleven strains of a hitherto undescribed Gram-positive, catalase-negative, facultatively anaerobic rod-shaped bacterium from human sources and medical care products were characterized by phenotypic and molecular taxonomic methods. The phenotypic properties of the bacterium were consistent with its assignment to the genus Lactobacillus but it was readily distinguished from all currently described species of this genus by its biochemical characteristics and by SDS-PAGE analysis of its cellular proteins. Comparative 165 rRNA gene sequence analysis demonstrated that the unknown bacterium was a member of rRNA group I Lactobacillus which includes Lactobacillus delbrueckii, the type species of the genus, and close relatives. Lactobacillus gasseri and Lactobacillus johnsonii were the nearest phylogenetic relatives of the unknown bacterium, but 165 rRNA sequence divergence values of $>4 \%$ clearly showed that it represents a distinct species. Based on both phylogenetic and phenotypic evidence, it is proposed that the unknown bacterium should be classified in the genus Lactobacillus, as Lactobacillus iners sp. nov. The type strain of Lactobacillus iners is CCUG $28746^{\top}$.
\end{abstract}

Keywords: Lactobacillus iners, taxonomy, phylogeny, rRNA

\section{INTRODUCTION}

The genus Lactobacillus comprises a phenotypically heterogeneous group of facultatively anaerobic, catalase-negative, non-spore-forming, Gram-positive, rod-shaped organisms which produce lactic acid as a major end-product of metabolism (Kandler \& Weiss, 1986). Lactobacillus species generally possess DNA with a low $\mathrm{G}+\mathrm{C}$ content (approx. 33-53 mol \%) and currently over 50 species are recognized. Lactobacilli are of great commercial importance due to their use in the production of a range of fermented dairy, meat and vegetable products and there is also now a growing interest in their use as probiotics (i.e. dietary adjuncts

tPresent address: Department of Food Science \& Technology, Earley Gate, University of Reading, Reading RG6 6BZ, UK.

Abbreviations: CCUG, Culture Collection of the University of Göteborg; RDP, Ribosomal Database Project.

The GenBank accession number for the 165 rRNA gene sequence of strain CCUG $28746^{\top}$ is $\mathrm{Y} 16329$. for man and animals) (Hammes et al., 1992). Lactobacilli are found in a great variety of habitats such as food, vegetation and sewage (Hammes et al., 1992). Several species of Lactobacillus are also found in association with humans, for example in the oral cavity, intestine and vagina. With the possible exception of a few isolated reports involving people with underlying disorders or disease, lactobacilli are considered non-pathogenic for man (Aguirre \& Collins, 1993).

During the course of an investigation of some Grampositive, catalase-negative, rod-shaped organisms from human sources, referred to the Culture Collection of the University of Göteborg (CCUG), Sweden, for identification, eleven strains of an unknown Lactobacillus-like bacterium were allocated to a provisional group, designated EF group 47. Preliminary phenotypic tests indicated that the isolates were possibly related to the genus Lactobacillus, but they could not be assigned to any recognized species. In this article, phenotypic characteristics of these strains and the 
results of a comparative 16S rRNA phylogenetic analysis are reported. Based on the taxonomic results presented, a new species, Lactobacillus iners, is described.

\section{METHODS}

Strains. Eleven catalase-negative, Gram-positive, rodshaped isolates were referred to the CCUG for identification. Strains CCUG 37448, CCUG 24626 and CCUG 38673 were from human endometrial, vaginal discharge and cervical (healthy 28-year-old female) specimens, respectively. Strains CCUG 27589, CCUG 28495, CCUG 28718, CCUG 28746 ${ }^{\mathrm{T}}$, CCUG 35443B and CCUG 37636 were recovered from human urine, whereas strains CCUG 37287 and CCUG 37289 originated from medical care products.

Biochemical tests. All strains were cultured on Columbia agar (Difco) supplemented with $5 \%$ horse blood at $37^{\circ} \mathrm{C}$ in air plus $\mathrm{CO}_{2}$. The strains were biochemically characterized using the API rapid ID32 strep and API ZYM systems according to the manufacturer's instructions (API bioMérieux).

Whole-cell protein analysis (SDSPAGE). The preparation of cellular protein extracts, SDS-PAGE, densitometric analysis, normalization and interpolation of the protein profiles, and numerical analysis were performed as described by Pot et al. (1994) using the Hoefer SE 600 vertical slab gel unit, Pharmacia-LKB UltroScan XL and the GELCOMPAR 3.0 software package (Applied Maths). The levels of similarity between pairs of traces were expressed by the Pearson product moment correlation coefficient converted for convenience to a percentage value.

Cell wall murein analysis. Preparation of the cell wall from strain CCUG $28746^{\mathrm{T}}$ and determination of murein structure were carried out using methods described by Schleifer \& Kandler (1972) except that TLC on cellulose sheets (Merck) was used instead of paper chromatography.

DNA base composition. DNA was isolated as described by Farrow et al. (1983) and the DNA G + C content (mol\%) was determined by thermal denaturation as described by Garvie (1978)

Determination of 16S rRNA gene sequences and phylogenetic analyses. A large fragment of the 16S rRNA gene was amplified by PCR using universal primers $\mathrm{pA}\left[5^{\prime}\right.$ AGAGTTTGATCCTGGCTCAG; positions 8-27 (Escherichia coli numbering)] and $\mathrm{pH}^{*}$ (5' AAGGAGGTGATCCAGCCGCA; positions 1541-1522). The PCR products were purified with a Prep-A-Gene kit (Bio-Rad) according to the manufacturer's instructions and were sequenced using a Taq DyeDeoxy Terminator Cycle Sequencing kit (Applied Biosystems) and a model 373A automatic sequencer (Applied Biosystems). The closest known relatives of the new isolates were determined by performing sequence database searches and the sequences of closely related strains were retrieved from GenBank or Ribosomal Database Project (RDP) libraries. Sequences were aligned with the PILEUP program (Devereux et al., 1984) and the alignment was corrected manually. Distance matrices were produced with the DNADIST program of the PHYLIP package (Felsenstein, 1989) and a phylogenetic tree was constructed according to the neighbour-joining method with the NEIGHBOR program (Felsenstein, 1989). The statistical significance of the groups obtained was assessed by bootstrapping ( 500 replicates) using the programs SEQBOOT, DNADIST, NEIGHBOR and CONSENSE (Felsenstein, 1989).

\section{RESULTS AND DISCUSSION}

Nine of the strains examined were isolated from human sources, i.e. urine (six strains), vaginal discharge (one strain), endometrial (one strain) and cervical (one strain) specimens, whereas the remaining two isolates were recovered from medical care products. All eleven strains were Gram-positive, non-spore-forming, rodshaped organisms which occurred as single cells, pairs or in short chains. The isolates were facultatively anaerobic and catalase- and oxidase-negative. The isolates grew on blood agar but not on MRS agar $(\mathrm{pH}$ 6.2 or $7 \cdot 3$ ) or Rogosa agar. Biochemically, the strains were relatively homogeneous and produced acid, but no gas, from glucose. Four out of the eleven strains also produced acid from maltose. However, with the exception of these sugars, the strains were asaccharolytic and did not produce acid from the following substrates: L-arabinose, D-arabitol, cyclodextrin, glycogen, $N$-acetylglucosamine, lactose, mannitol, melezitose, melibiose, methyl $\beta$-D-glucopyranoside, pullulan, raffinose, ribose, rhamnose, sorbitol, sucrose, tagatose, trehalose or D-xylose. All of the strains displayed alanine-phenylalanine-proline arylamidase, esterase $\mathrm{C} 4, \alpha$-glucosidase, leucine arylamidase and phosphoamidase activity. None of the strains exhibited alkaline phosphatase, arginine dihydrolase, chymotrypsin, $\alpha$-fucosidase, $\alpha$-galactosidase, $\beta$-galactosidase, $\beta$-galacturonidase, $\beta$-glucosidase, $\beta$-glucuronidase, glycyl-tryptophan arylamidase, $\alpha$-mannosidase, $\beta$ mannosidase, lipase C14, trypsin or urease activity. The strains hydrolysed hippurate, but not aesculin or gelatin. All were Voges-Proskauer-negative and failed to reduce nitrate. Seven strains were examined by SDS-PAGE analysis of whole-cell proteins which confirmed the high overall phenotypic homogeneity of the isolates. The seven strains formed a tight cluster and were readily separated from all other reference Lactobacillus species examined using this technique (Fig. 1). Cell wall analysis of strain CCUG $28746^{\mathrm{T}}$ revealed the presence of murein type L-Lys-D-Asp, which is found in many lactobacilli and other lactic acid bacteria (Hammes et al., 1992; Schleifer \& Kandler, 1972). The G + C content of DNA of strain CCUG $28746^{\mathrm{T}}$ was determined as $34.4 \mathrm{~mol} \%$. This value is at the lower end of the DNA G $+\mathrm{C}$ range of the genus Lactobacillus (approx. range 33-53 mol \%), but nevertheless compatible with the assignment of the unknown bacterium to this genus.

To establish the phylogenetic position of the unknown bacterium, the 16S rRNA genes of three representative strains were amplified by PCR and characterized by sequence analysis. The almost complete gene sequence ( $>1400$ nucleotides) of strain CCUG $28746^{\mathrm{T}}$ was determined and sequence searches of GenBank and RDP libraries revealed that the unknown rod was phylogenetically a member of the rRNA group I Lactobacillus (Lactobacillus delbrueckii group of organisms; see Collins et al., 1991). Treeing analysis confirmed this placement and showed that the unknown bacterium was phylogenetically most closely 


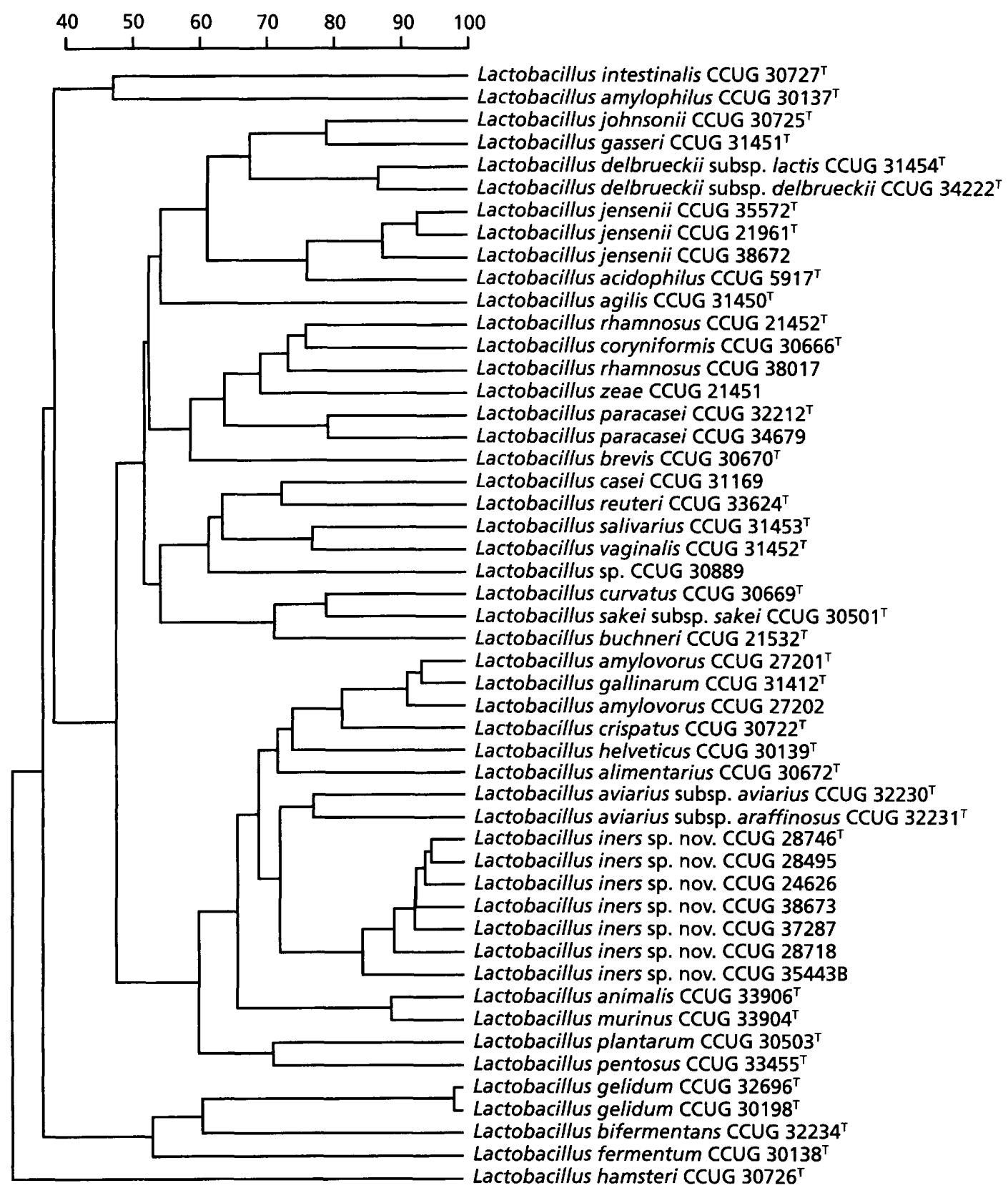

Fig. 1. Similarity dendrogram based on whole-cell protein patterns of Lactobacillus iners sp. nov. and related species. Levels of correlation are expressed as percentages of similarity for convenience.

related to Lactobacillus gasseri and Lactobacillus johnsonii (approx. 96\% sequence similarity). Bootstrap resampling (value $100 \%$ ) showed that the association between the unknown rod and L. gasseri/L. johnsonii was statistically significant (Fig. 2). Approximately 1000 nucleotides of the 16S rRNA genes of two other strains (CCUG 24626 and CCUG 28495) of the unknown bacterium were also determined. Pairwise analysis showed these to be identical $(100 \%$ sequence similarity) to that of strain CCUG $28746^{\mathrm{T}}$, thereby demonstrating high genealogical relatedness of the isolates.
The results of biochemical and whole-cell protein SDSPAGE analyses showed that the unknown, catalasenegative, Gram-positive, asporogenous, rod-shaped isolates represent a homogeneous group of organisms and constitute a new species. Phylogenetically, the unknown bacterium clustered with the Lactobacillus delbrueckii group of species (rRNA group I Lactobacillus; see Collins et al., 1991) and showed a specific association with $L$. gasseri and L. johnsonii. $16 \mathrm{~S}$ rRNA sequence divergence values of $>4 \%$ with these two species, however, showed that the unidentified bacterium represents a hitherto unrecognized species within rRNA group I Lactobacillus. It is pertinent to 


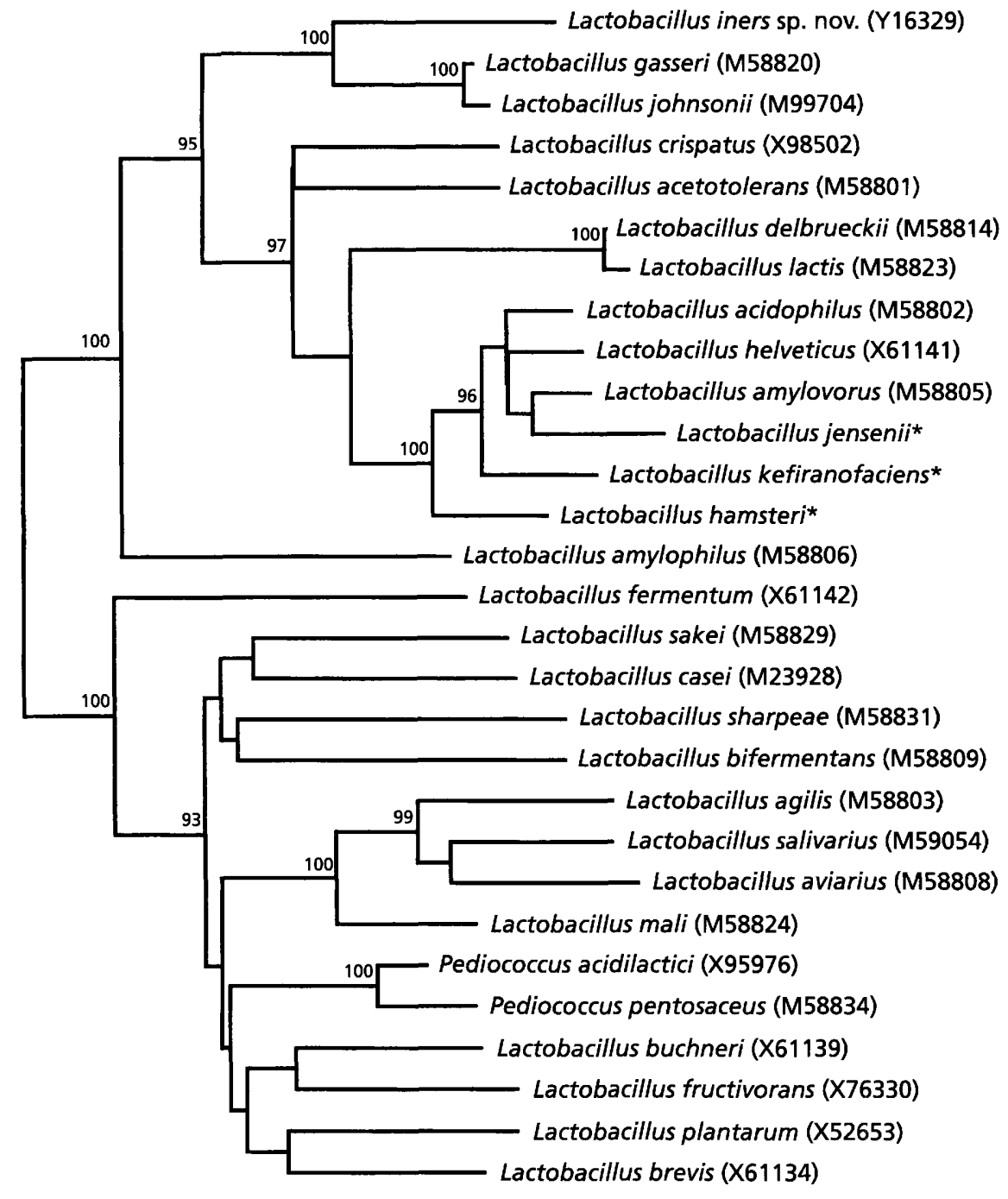

Fig. 2. Unrooted tree showing the phylogenetic relationships of Lactobacillus iners sp. nov. and closely related lactic acid bacteria. All strains are type strains. The tree constructed using the neighbour-joining method was based on a comparison of approx. 1320 nucleotides. Bootstrap values, expressed as a percentage of 500 replications, are given at branching points. *Sequences from the Institute of Food Research database, Reading, UK.

note that the majority of the isolates of the unknown Lactobacillus were recovered from adult women (e.g. urine, vaginal discharge). Lactobacilli have long been known to be residents of normal vaginal flora of women. The predominant vaginal Lactobacillus species are considered to be Lactobacillus acidophilus and Lactobacillus fermentum (Eschenbach et al., 1989; Rogosa \& Sharpe, 1960; Wylie \& Henderson, 1969). However, some of the organisms routinely assigned to L. acidophilus correspond to L. gasseri or Lactobacillus crispatus (Hammes et al., 1992). Several other lactobacilli (e.g. Lactobacillus casei, L. fermentum, $L$. delbrueckii, Lactobacillus jensenii, Lactobacillus salivarius) are recognized as minor components of the human vaginal flora. A new species, Lactobacillus vaginalis, has been described by Embley et al. (1989) from the vagina of patients suffering from tricho- moniasis. The unknown rod reported in this study is phylogenetically quite distinct from the above-mentioned species. In addition, the unidentified bacterium is biochemically readily distinguishable from these and all other currently described lactobacilli, by its relatively asaccharolytic nature. Therefore, based on its phenotypic and phylogenetic distinctiveness, it is considered that the unidentified bacterium represents a hitherto unrecognized species, for which the name Lactobacillus iners sp. nov. is proposed.

\section{Description of Lactobacillus iners sp. nov.}

Lactobacillus iners (L. adj. iners inert, lazy).

Cells are rod-shaped and occur singly, in pairs or in short chains. After $24 \mathrm{~h}$ incubation on blood agar, under anaerobic conditions, colonies are small 
( $<1 \mathrm{~mm}$ diameter), smooth, circular, translucent and non-pigmented. Old cultures display a 'fried egg' appearance. Cells stain Gram-positive and are nonspore-forming and non-motile. Catalase-negative and facultatively anaerobic. Grows on blood agar, but not MRS agar or Rogosa agar. Grows in the presence of $1.5 \% \mathrm{NaCl}$, but not $3 \% \mathrm{NaCl}$. Does not grow at $15{ }^{\circ} \mathrm{C}$ but grows at 30 and at $42{ }^{\circ} \mathrm{C} . \mathrm{L}(+)$-Lactic acid is produced from glucose without gas. Some strains produce acid from maltose. Acid is not produced from L-arabinose, D-arabitol, cyclodextrin, glycogen, $N$ acetyl- $\beta$-glucosamine, lactose, mannitol, melezitose, melibiose, methyl $\beta$-D-glucopyranoside, pullulan, raffinose, ribose, rhamnose, sorbitol, sucrose, tagatose, trehalose or D-xylose. Positive for alanine-phenylalanine-proline arylamidase, esterase $\mathrm{C} 4, \alpha$-glucosidase, leucine arylamidase and phosphoamidase. Negative for alkaline phosphatase, arginine dihydrolase, chymotrypsin, $\alpha$-fucosidase, $\alpha$-galactosidase, $\beta$-galactosidase, $\beta$-galacturonidase, $\beta$-glucosidase, $\beta$-glucuronidase, glycyl-tryptophan arylamidase, $\alpha$-mannosidase, $\beta$ mannosidase, lipase $\mathrm{C} 14$, trypsin and urease. Acid phosphatase, ester lipase C8 and pyroglutamic acid arylamidase activity is detected in some strains. Hippurate is hydrolysed, but not aesculin or gelatin. Nitrate is not reduced. Voges-Proskauer-negative. The cell wall murein type is L-Lys-D-Asp (A $4 \alpha$ ). Isolated from human clinical specimens (urine, vagina) and medical care products. The type strain is CCUG $28746^{\mathrm{T}}$. The $\mathrm{G}+\mathrm{C}$ content of CCUG $28746^{\mathrm{T}}$ is $34.4 \mathrm{~mol} \%$ (thermal denaturation method). The type strain has the characteristics of the species but is negative for acid phosphatase, ester lipase C8 and pyroglutamic acid arylamidase.

\section{ACKNOWLEDGEMENTS}

This work was supported in part by grants from the European Union (B102-CT93-0119; B102-CT94-3098). We thank the depositors of the isolates (viz: Dr Knut Lincoln, Marie Blomkvist, Inger Mattsby and the Public Health Laboratory Services).

\section{REFERENCES}

Aguirre, M. \& Collins, M. D. (1993). Lactic acid bacteria and human clinical infection. J Appl Bacteriol 75, 95-107.
Collins, M. D., Rodrigues, U., Ash, C., Aguirre, M., Farrow, J. A. E., Martinez-Murcia, A., Phillips, B. A., Williams, A. M. \& Wallbanks, S. (1991). Phylogenetic analysis of the genus Lactobacillus and related lactic acid bacteria as determined by reverse transcriptase sequencing of $16 \mathrm{~S}$ rRNA. FEMS Microbiol Lett 77 , 5-12.

Devereux, J., Haeberli, P. \& Smithies, O. (1984). A comprehensive set of sequence analysis program for the VAX. Nucleic Acids Res 12, 387-395.

Embley, T. M., Faquir, N., Bossart, W. \& Collins, M. D. (1989). Lactobacillus vaginalis $\mathrm{sp}$. nov. from the human vagina. Int $J$ Syst Bacteriol 39, 368-370.

Eschenbach, D. A., Davick, P. R., Williams, B. L., Klebanoff, S. J., Young-Smith, K., Critchlow, C. M. \& Holmes, K. K. (1989). Prevalence of hydrogen peroxide-producing Lactobacillus species in normal women and women with bacterial vaginosis. $J$ Clin Microbiol 27, 251-256.

Farrow, J. A. E., Jones, D., Phillips, B. A. \& Collins, M. D. (1983). Taxonomic studies on some group D streptococci. J Gen Microbiol 129, 1423-1432.

Felsenstein, J. (1989). PHYLIP - phylogeny inference package (version 3.2). Cladistics 5, 164-166.

Garvie, E. I. (1978). Streptococcus raffinolactis (Orla-Jensen and Hansen); a group $\mathrm{N}$ streptococcus found in raw milk. Int $J$ Syst Bacteriol 28, 190-193.

Hammes, W. P., Weiss, N. \& Holzapfel, W. (1992). The genera Lactobacillus and Carnobacterium. In The Prokaryotes, 2nd edn, pp. 1535-1594. Edited by A. Balows, H. G. Trüper, M. Dworkin, W. Harder \& K.-H. Schleifer. New York: Springer.

Kandler, O. \& Weiss, N. (1986). Genus Lactobacillus. In Bergey's Manual of Systematic Bacteriology, vol. 2, pp. 1209-1234. Edited by P. H. A. Sneath, N. S. Mair, M. E. Sharpe \& J. G. Holt. Baltimore: Williams \& Wilkins.

Pot, B., Vandamme, P. \& Kersters, K. (1994). Analysis of electrophoretic whole-organism protein fingerprints. In Modern Microbial Methods (Chemical Methods in Prokaryotic Systematics Series), pp. 492-521. Edited by M. Goodfellow \& A. G. O'Donnell. Chichester: Wiley.

Rogosa, M. \& Sharpe, M. E. (1960). Species differentiation of human vaginal lactobacilli. J Gen Microbiol 23, 197-201.

Schleifer, K.-H. \& Kandler, O. (1972). Peptidoglycan types of bacterial cell walls and their taxonomic implications. Bacteriol Rev 36, 407-477.

Wylie, J. G. \& Henderson, A. (1969). Identity and glycogenfermenting ability of lactobacilli isolated from the vagina of pregnant women. J Med Microbiol 2, 363-366. 